\title{
Validation and Application of a Real-time PCR Protocol for the Specific Detec- tion and Quantification of Clavibacter michiganensis subsp. sepedonicus in Potato
}

\author{
Min Seok Cho ${ }^{1,3, \uparrow}$, Duck Hwan Park ${ }^{2, \uparrow}$, Min Namgung ${ }^{2}$, Tae-Young Ahn ${ }^{3}$ and Dong Suk Park ${ }^{1 *}$ \\ ${ }^{I}$ National Academy of Agricultural Science, Rural Development Administration, Jeonju 560-550, Korea \\ ${ }^{2}$ Department of Applied Biology, College of Agriculture and Life Sciences, Kangwon National University, Chuncheon 200- \\ 701, Korea \\ ${ }^{3}$ Department of Microbiology, Dankook University, Cheonan 330-714, Korea
}

(Received on February 5, 2015; Revised on March 20, 2015; Accepted on March 20, 2015)

Clavibacter michiganensis subsp. sepedonicus (Cms) multiplies very rapidly, passing through the vascular strands and into the stems and petioles of a diseased potato. Therefore, the rapid and specific detection of this pathogen is highly important for the effective control of the pathogen. Although several PCR assays have been developed for detection, they cannot afford specific detection of $\mathrm{Cms}$. Therefore, in this study, a computational genome analysis was performed to compare the sequenced genomes of the $C$. michiganensis subspecies and to identify an appropriate gene for the development of a subspecies-specific PCR primer set (Cms89F/ $R)$. The specificity of the primer set based on the putative phage-related protein was evaluated using genomic DNA from seven isolates of $\mathrm{Cms}$ and 27 other reference strains. The $\mathrm{Cms89F/R}$ primer set was more specific and sensitive than the existing assays in detecting $\mathrm{Cms}$ in in vitro using $C m s$ cells and its genomic DNA. This assay was also able to detect at least $1.47 \times 10^{2}$ copies/ $\mu \mathrm{l}$ of cloned-amplified target DNA, 5 fg of DNA using genomic DNA or $10^{-6}$ dilution point of 0.12 at $\mathrm{OD}_{600}$ units of cells per reaction using a calibrated cell suspension.

Keywords : bacterial ring rot, Clavibacter michiganensis subsp. sepedonicus, detection, putative phage-related protein, potato, real-time PCR

Bacterial ring rot, which is caused by the gram-positive bacterium Clavibacter michiganensis subsp. sepedonicus $(\mathrm{Cms})$, occurs throughout potato-growing regions world-

\footnotetext{
These authors contributed equally to this work.

*Corresponding author.

Phone) +82-63-238-4581, FAX) +82-63-238-4584

E-mail)dspark@rda.go.kr
}

wide (Kado, 2010). This pathogen is mainly transmitted through noncertified potato seed pieces that were handled without care during the preparation of seed cutting (Manzer and Genereux, 1981). Improper sanitation methods that are used during cool temperature storage and in planting machinery can also spread the pathogen to new seed pieces (Bonde, 1942). Thus, Cms cells are easily transferred to new sites, resulting in the classification of this pathogen as highly contagious. Because of the highly contagious nature of the ring rot pathogen, many countries have implemented a quarantine program with a zero-tolerance policy (Gutbrod, 1987). In order to agree with this policy, seed and plant bioassays have firstly required the global adoption and acceptance of rapid and reliable tests by independent laboratories or institutions, including tests for new strains and hosts. Nevertheless, some of these assays cannot detect the pathogen and have some limitations.

In general, the diagnosis of $\mathrm{Cms}$ is based on the isolation of the pathogen, followed by Gram staining combined with a bioassay and morphological and biochemical characteristics and/or semi-selective medium and pathogenicity tests (Bishop and Slack, 1987; Cruz et al., 1992). Such tests require one to several weeks before final confirmation is obtained. Currently, serological and molecular assays based on immunofluorescent-antibody staining (IFA), enzymelinked immunosorbent assay (ELISA), and PCR are widely used to detect Cms strains; however, because these assays also detect other closely related bacterial strains, there have been critical defects in the diagnosis and identification of Cms isolates (De Boer and Wieczorek, 1984; De Boer et al., 1988; Hu et al., 1995; Lee et al., 1997; Li and De Boer, 1995; Li et al., 2006; Mackay et al., 2002; Mills et al., 1997; Pastrik, 2000; Rademaker and Janse, 1994; Schaad et al., 1999; Schneider et al., 1993). Previous studies have developed a real-time PCR method using the cellulase A (CelA) gene from a small cryptic plasmid (pCS1), but 
plasmid-based genetic sequences are still quite variable (Gudmestad et al., 2009).

Recently, a number of bioinformatics applications have been proposed or innovatively used to identify discriminatory bacterial species- and subspecies-specific markers for bacterial detection and identification (Albuquerque et al., 2009; Chen et al., 2010; Cho et al., 2011; Lang et al., 2010).

In this study, Cms $89 \mathrm{~F} / \mathrm{R}$ primer was identified using a comparative analysis of the subspecies group of genome sequences of $C$. michiganensis. Additionally, a SYBR Green qPCR assay was developed to detect $C m s$ based on Cms89F/R. The efficiency, specificity and sensitivity of putative phage-related proteins were evaluated, and the efficacy of the analytical method to detect $\mathrm{Cms}$ in both symptom and symptomless tubers was demonstrated.

\section{Materials and Methods}

Bacterial strains and culture conditions. The bacterial

Table 1. The bacterial strains used in this study

\begin{tabular}{|c|c|c|c|}
\hline No. & Bacteria Name & Source & Geographical origin \\
\hline 1 & Clavibacter michiganensis subsp. sepedonicus ${ }^{\mathrm{a}}$ & NCPPB 2137 & Canada \\
\hline 2 & Clavibacter michiganensis subsp. sepedonicus & LMG 2897 & United States \\
\hline 3 & Clavibacter michiganensis subsp. sepedonicus & LMG 5861 & Sweden \\
\hline 4 & Clavibacter michiganensis subsp. sepedonicus & NCPPB 3384 & Norway \\
\hline 5 & Clavibacter michiganensis subsp. sepedonicus & NCPPB 3896 & United Kingdom \\
\hline 6 & Clavibacter michiganensis subsp. sepedonicus & NCPPB 3916 & Argentina \\
\hline 7 & Clavibacter michiganensis subsp. sepedonicus & NCPPB 4218 & Czech Republic \\
\hline 8 & Clavibacter michiganensis subsp. michiganansis $s^{\mathrm{a}}$ & LMG 7333 & Hungary \\
\hline 9 & Clavibacter michiganensis subsp. insidiosus ${ }^{\mathrm{a}}$ & LMG 3663 & United States \\
\hline 10 & Clavibacter michiganensis subsp. nebraskensis ${ }^{\mathrm{a}}$ & LMG 3700 & United States \\
\hline 11 & Clavibacter michiganensis subsp. tesselarius ${ }^{\mathrm{a}}$ & NCPPB 3664 & United States \\
\hline 12 & Clavibacter rathayi $^{\mathrm{a}}$ & LMG 7288 & New Zealand \\
\hline 13 & Ralstonia solanacearum $^{\mathrm{T}}($ Race 1 / Biovar 1$)$ & LMG 2299 & United States \\
\hline 14 & Ralstonia solanacearum (Race 1 / Biovar 3) & LMG 2305 & Egypt \\
\hline 15 & Ralstonia solanacearum (Race 1 / Biovar 4) & KACC 10704 & Republic of Korea \\
\hline 16 & Ralstonia solanacearum (Race 1 / Biovar -) & KACC 11179 & Republic of Korea \\
\hline 17 & Ralstonia solanacearum (Race 3 / Biovar 2) & KACC 10716 & Republic of Korea \\
\hline 18 & Ralstonia mannitolilytica ${ }^{\mathrm{a}}$ & LMG 6866 & United Kingdom \\
\hline 19 & Ralstonia pickettii ${ }^{\mathrm{a}}$ & LMG 5942 & United States \\
\hline 20 & Pseudmonas syringae pv. antirrhini ${ }^{\mathrm{a}}$ & NCPPB 1817 & United Kingdom \\
\hline 21 & Pseudmonas syringae pv. berberidis ${ }^{\mathrm{a}}$ & NCPPB 2724 & New Zealand \\
\hline 22 & Pseudmonas syringae pv. persicae ${ }^{\mathrm{a}}$ & NCPPB 2761 & France \\
\hline 23 & Pseudmonas syringae pv. lachrymans ${ }^{\mathrm{a}}$ & NCPPB 2916 & Zimbabwe \\
\hline 24 & Pseudmonas syringae pv. maculicola ${ }^{\mathrm{a}}$ & LMG 5071 & New Zealand \\
\hline 25 & Pseudmonas syringae pv. tomato ${ }^{\mathrm{a}}$ & LMG 5093 & United Kingdom \\
\hline 26 & Burkholderia gladioli pv. gladioli & LMG 2216 & United States \\
\hline 27 & Xanthomonas campestris pv. campestris ${ }^{\mathrm{a}}$ & LMG 568 & United Kingdom \\
\hline 28 & Xanthomonas axonopodis pv. citri & KACC 10443 & Republic of Korea \\
\hline 29 & Xanthomonas axonopodis pv. vesicatoria & LMG 905 & - \\
\hline 30 & Xanthomonas vesicatoria & LMG 921 & United States \\
\hline 31 & Erwinia persicina ${ }^{\mathrm{a}}$ & LMG 11254 & Japan \\
\hline 32 & Pectobacterium carotovorum subsp. atrosepticum ${ }^{\mathrm{a}}$ & LMG 2386 & United Kingdom \\
\hline 33 & Pectobacterium carotovorum subsp. carotovorum ${ }^{\mathrm{a}}$ & LMG 2404 & Denmark \\
\hline 34 & Escherichia coli & LMG 2092 & Denmark \\
\hline
\end{tabular}

KACC, Korean Agricultural Culture Collection, Republic of Korea (http://www.genebank.go.kr/); LMG, The Belgian Co-ordinated Collections of Microorganisms $\left(\mathrm{BCCM}^{\mathrm{TM}}\right)$, Belgium; NCPPB, National Collection of Plant Pathogenic Bacteria.

${ }^{a}$ Type strain. 
strains that were used in this study were obtained from the Belgian Coordinated Collections of Microorganisms (BCCM), the Korean Agricultural Culture Collection (KACC), and the National Collection of Plant Pathogenic Bacteria (NCPPB) in the United Kingdom. Bacterial strains are listed in Table 1. The culture media and incubation conditions were taken from the Handbook of Microbiological Media (Atlas, 2004). The Clavibacter species were grown on yeast extract glucose mineral salts agar (YGM-Agar) at $23^{\circ} \mathrm{C}$.

DNA extraction. Clavibacter strains were cultured on YGM medium and harvested with a scraper for total genomic DNA extraction. The total genomic DNA from the other microorganisms was prepared using a DNeasy Tissue kit (QIAGEN, Hilden, Germany) according to the manufacturer's instructions. A Nanodrop ${ }^{\mathbb{B}}$ ND-1000 Spectrophotometer (NanoDrop Technologies, Wilmington, DE, U.S.A.) was used to measure the genomic DNA concentration. The total genomic DNA of the bacterial strains was diluted in TE buffer ( $\mathrm{pH} 8.0$ ) to $25 \mathrm{ng} / \mu \mathrm{l}$.

Comparative genomic analysis and primer design. The genomes of $C$. michiganensis subspecies were compared using bioinformatics tools. A search algorithm was used to identify orthologues among Cms, C. m. subsp. michiganensis and C. $m$. subsp. nebraskensis. The data on the genomic sequences and annotations were obtained from the NCBI GenBank database (ftp://ftp.ncbi.nlm.nih.gov/ genomes/bacteria/). The candidate target genes were selected using a method that was modified from Chen (Chen et al., 2010) and Lang (Lang et al., 2010). The NCBI programs BLASTN, BLASTX and Conserved Domains were used to conduct similarity and domain searches of the candidate target genes. The candidate target genes of $\mathrm{Cms}$ ATCC 33113 were screened by comparative genomics. In particular, the putative phage-related protein (GenBank accession No. CAQ00928, gi|169155030:861988-863124) was selected among the candidate genes of the Cms ATCC 33113 genome. The oligonucleotide sequences of the primer sets are presented in Table 2. The primers and probes for the qPCR were synthesised by Bioneer Corporation (Daejeon, Korea), respectively.

Conventional and real-time PCR conditions. The thermocycling conditions that were used for the conventional PCR reactions consisted of the following: initial denaturation for $5 \mathrm{~min}$ at $95^{\circ} \mathrm{C}$; followed by 35 cycles of $1 \mathrm{~min}$ at $95^{\circ} \mathrm{C}, 30$ seconds at $59^{\circ} \mathrm{C}$, and $1 \mathrm{~min}$ at $72^{\circ} \mathrm{C}$; and a final extension of $7 \mathrm{~min}$ at $72^{\circ} \mathrm{C}$. The PCR amplifications were conducted in volumes of $25 \mu \mathrm{l}$ in a PTC-225 thermocycler (MJ Research, Watertown, MA, USA). The real-time PCR amplification was performed using a CFX96 realtime PCR system (Bio-Rad laboratories, Inc., USA) with the following cycling conditions: initial denaturation for 30 $\mathrm{s}$ at $95^{\circ} \mathrm{C}$; then 45 cycles of $5 \mathrm{~s}$ at $95^{\circ} \mathrm{C}, 30 \mathrm{~s}$ at $59^{\circ} \mathrm{C}$, and a melting curve of $65^{\circ} \mathrm{C}$ to $95^{\circ} \mathrm{C}$ at an increment of $0.5^{\circ} \mathrm{C}$. The SYBR green real-time qPCR assay was performed in a 20- $\mu$ l reaction. The TaqMan qPCR amplification of the Cms50, Cms72a and CelA primer sets was performed under previously described conditions (Gudmestad et al., 2009) (Table 2). The conventional and real-time PCR amplifications were carried out with the above primers (at a final concentration of $0.5 \mu \mathrm{M})$, GoTaq $^{\circledR}$ DNA polymerase

Table 2. PCR primers and probes, their target and annealing temperature, of the Clavibacter michiganensis subsp. sepedonicus PCR screenings used in this study

\begin{tabular}{|c|c|c|c|}
\hline Primer/probe ${ }^{a}$ & Sequences $\left(5^{\prime}-3^{\prime}\right)$ & Amplicon size (bp) & Reference \\
\hline Cms50 & $\begin{array}{l}\text { GAGCGCGATAGAAGAGGAACTC } \\
\text { CCTGAGCAACGACAAGAAAAATATG } \\
\text { [FAM] TGAAGATGCGACATGGCTCCTCGGT [BH1] }\end{array}$ & 192 & Gudmestad et al., 2009 \\
\hline Cms72a & $\begin{array}{l}\text { CTACTTTCGCGGTAAGCAGTT } \\
\text { GCAAGAATTTCGCTGCTATCC } \\
\text { [CY5] GATCGTGAATCCGAGACACGGTGACC [BH2] }\end{array}$ & 213 & Gudmestad et al., 2009 \\
\hline CelA & $\begin{array}{l}\text { TCTCTCAGTCATTGTAAGATGAT } \\
\text { ATTCGACCGCTCTCAAA } \\
\text { [HEX] TTCGGGCTTCAGGAGTGCGTGT [BH2] }\end{array}$ & 150 & Gudmestad et al., 2009 \\
\hline Cms89 & $\begin{array}{l}\text { CCACGGACACGTCTGATGCT } \\
\text { CCTTGGCGACGGTTCAGAGA }\end{array}$ & 89 & This study \\
\hline
\end{tabular}

${ }^{a}$ GenBank accession number Cms50 is the hypothetical protein (gi:169156701), Cms72a is the putative ATP-binding protein (gi:169155399), CelA is the Cms plasmid pCS1/cellulase CelA (gi:169157974), Cms89 is the putative phage-related protein (gi:169155803). 
(1.25 $\mu \mathrm{M}$ final concentration; Promega, Madison, Wisconsin, USA) and SYBR ${ }^{\circledR}$ Premix Ex Taq ${ }^{\mathrm{TM}}$ (TAKARA $\mathrm{BIO}$, Inc., Japan) according to the manufacturer's instructions, using approximately $5 \mathrm{ng}$ of purified DNA from each sample. After the conventional PCR reaction, $10 \mu \mathrm{l}$ of the each PCR product was electrophoresed through a 1.5\% agarose gel, stained with ethidium bromide, visualised on a UV transilluminator and imaged using a VersaDoc 1000 gel imaging system (Bio-Rad Laboratories, Inc., USA).

Specificity and sensitivity of the SYBR Green real-time qPCR assay. The specificity of the primer set Cms89FF/R was tested against a total of 12 strains of $C$. michiganensis subspecies and 22 bacterial strains from seven other genera. For sensitivity testing, the cloned DNA, total genomic DNA, and bacterial cell suspension from $C m s$ NCPPB 2137 were serial diluted ten-fold and tested by SYBR Green real-time qPCR. The sensitivity evaluations were reproduced using serial dilutions and SYBR green real-time qPCR testing in triplicate. The data analysis, which included the determination of a standard curve, cycle threshold $\left(\mathrm{C}_{\mathrm{t}}\right)$ or quantification cycle $\left(\mathrm{C}_{\mathrm{q}}\right)$ value, PCR efficiencies, and slope of the standard curve, was automatically performed by the CFX Manager ${ }^{\mathrm{TM}}$ Software system (Version 1.6; Bio-Rad Laboratories, Inc., USA). A copy number of the cloned DNA was calculated using the following equation:

Copies $/ \mathrm{ul}=\left[6.022 \times 10^{23}(\right.$ copy $/ \mathrm{mol}) \times$ amount $\left.(\mathrm{g})\right] /$ [length $(\mathrm{bp}) \times 660(\mathrm{~g} / \mathrm{mol} / \mathrm{bp})]$ (Whelan et al., 2003).

Inoculation and sample preparation. $\mathrm{Cms}$-free potato tubers (Solanum tuberosum L. 'Atlantic') were removed from a cold storage facility one week prior to cutting and were inoculated as previously described (Slack et al., 1996). Briefly, the tubers were cut with one or two eyes and allowed to suberize for two days at room temperature. Then, the seed pieces were wounded by inserting a yellow pipette tip in both sides of the eye and then inoculating with $2 \mu 1$ of a bacterial suspension $\left(\mathrm{OD}_{600 \mathrm{~nm}}=2.0\right)$ containing either the NCPPB 2137 strain. The control seed pieces were inoculated with $2 \mu \mathrm{l}$ of sterile distilled water. After inoculation, the seed pieces were allowed to rest for $30 \mathrm{~min}$ to stabilise the Cms. The pieces were then sown in $20-\mathrm{cm}-$ diameter pots that were filled with an autoclaved artificial soil mixture; the sowed pieces were subsequently placed inside a greenhouse. The temperature inside of the greenhouse ranged from 20 to $25^{\circ} \mathrm{C}$ during the growing periods, and the tubers were watered daily until they reached the four-leaf stage. The experiment was carried out in a com-

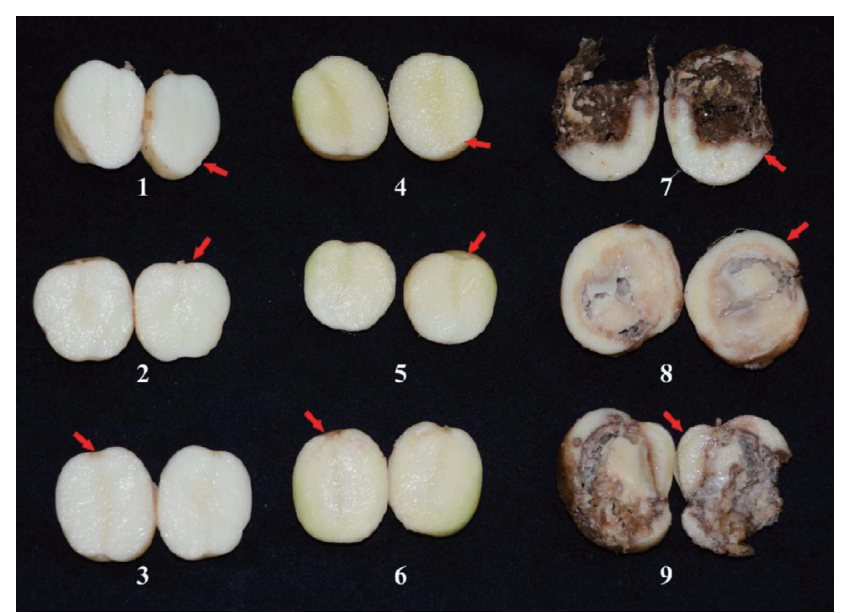

Fig. 1. Sampling area of the infected potato tuber (Solanum tuberosum L. 'Atlantic'). The assays were performed using the harvested tubers from seed-inoculate method with Clavibacter michiganensis subsp. sepedonicus NCPPB 2137.

pletely randomised blocked design with 15 tubers from five plants in each group and with each pot distant from the other pots to avoid cross-contamination. The $1-\mathrm{g}$ samples were taken from an area of $1 \mathrm{~cm}$ that was distant from the symptom and symptomless lesion at 90 days post inoculation (dpi) as depicted in Fig. 1. Each sample was dipped in $500 \mu \mathrm{l}$ of sterile distilled water for $30 \mathrm{~min}$. The water that was treated with each sample $(1 \mu \mathrm{l})$ was used in the SYBR green real-time bio-qPCR assays as described above.

\section{Results}

Bioinformatic analysis and primer design. Using the computational approach based on comparative genomics, a set of diagnostic primers was identified that distinguishes between three closely related pathogens: $C$. $m$. subsp. sepedonicus, C. m. subsp. michiganensis and C. m. subsp. nebraskensis (Lang et al., 2010). This approach also revealed some significant matches with previously determined sequences (BLASTN ver. 2.2.28+). BLASTN searches showed similarity to the conserved hypothetical protein sequence $[$ identity $=82 \%$, Score $=976$ bits (528), Expect $=0.0$, and Gaps $=8 / 1141]$ from C. $m$. subsp. nebraskensis NCPPB 2581. BLAST searches with the predicted protein sequence (BLASTX) revealed similarities with the conserved hypothetical protein sequence [identity $=85 \%$, Score $=621$ bits (1601), and Expect=0.0] from C. $m$. subsp. nebraskensis NCPPB 2581 and the hypothetical protein sequence [identity $=33 \%$, Score $=149$ bits (376), and Expect $=9 \mathrm{e}-38]$ from Blastococcus saxobsidens DD2. However, the region to be amplified with the designed primer set revealed no signifi- 


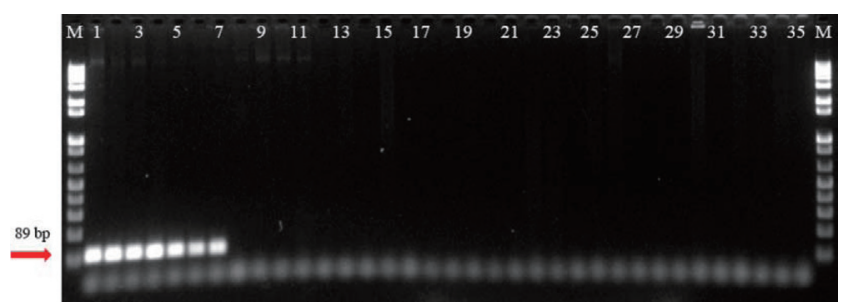

Fig. 2. Specific PCR amplification of a putative phage-related protein fragment from Clavibacter michiganensis subsp. sepedonicus with the primer set $\mathrm{Cms} 89 \mathrm{~F} / \mathrm{R}$. Lane $\mathrm{M}$, size marker (1 kb DNA plus ladder; Gibco BRL); lanes 1-34 are listed in Table 1; and lane 35 contains distilled water.

cant match in either the BLASTN or BLASTX searches.

Specificity of the PCR assay. The specificity of the Cms89F/ $\mathrm{R}$ primer sets was evaluated by conventional PCR and by the SYBR green real-time qPCR assay using reference strains (Table 1). Cms produced a positive band with the expected DNA fragment length ( $89 \mathrm{bp}$ ); however, the other Clavibacter subspecies strains and reference microorganisms did not produce any amplification product (Fig. 2). Only the assays with Cms yielded amplified products with fluorescence intensity and a single amplified DNA fragment. No signal was obtained from the negative control of the amplification reaction (NTC).

Sensitivity test by SYBR Green qPCR. A standard curve that was based on cloned DNA was constructed to determine the Cms NCPPB 2137 concentration; a ten-fold serial dilution factor was used to achieve $1.47 \times 10^{9}$ gene copies per SYBR green qPCR. The amplification product of the targeted gene (putative phage-related protein) was cloned and used as control DNA for quantification. This assay was able to quantify at least 1.47 copies $/ \mu$ of target DNA. The standard curve revealed a good linear response $\left(\mathrm{R}^{2}=0.995\right)$. The standard regression analysis of the linear part of the slope produced a coefficient of -3.050 , yielding a PCR efficiency of $112.7 \%$ (Fig. 3A). The analysis of the melting temperature and melting peaks of $\mathrm{Cms}$ by the SYBR green qPCR revealed a reproducible melting temperature of $83^{\circ} \mathrm{C}$ and specific peaks (Fig. 3B). The standard curves revealed a linear correlation between the $\mathrm{C}_{\mathrm{t}}$ values and the concentrations of genomic DNA $\left(\mathrm{R}^{2}=0.998\right.$, slope $\left.=-3.163\right)$ and bacterial cell suspension $\left(\mathrm{R}^{2}=0.994\right.$, slope $\left.=-3.068\right)$ of Cms NCPPB 2137.

The limit of detection (LOD) was determined for the genomic DNA and bacterial cells as the probability of having a positive SYBR green real-time $\mathrm{qPCR}$ result greater than $95 \%$. Measuring the proportion of positive replicates per
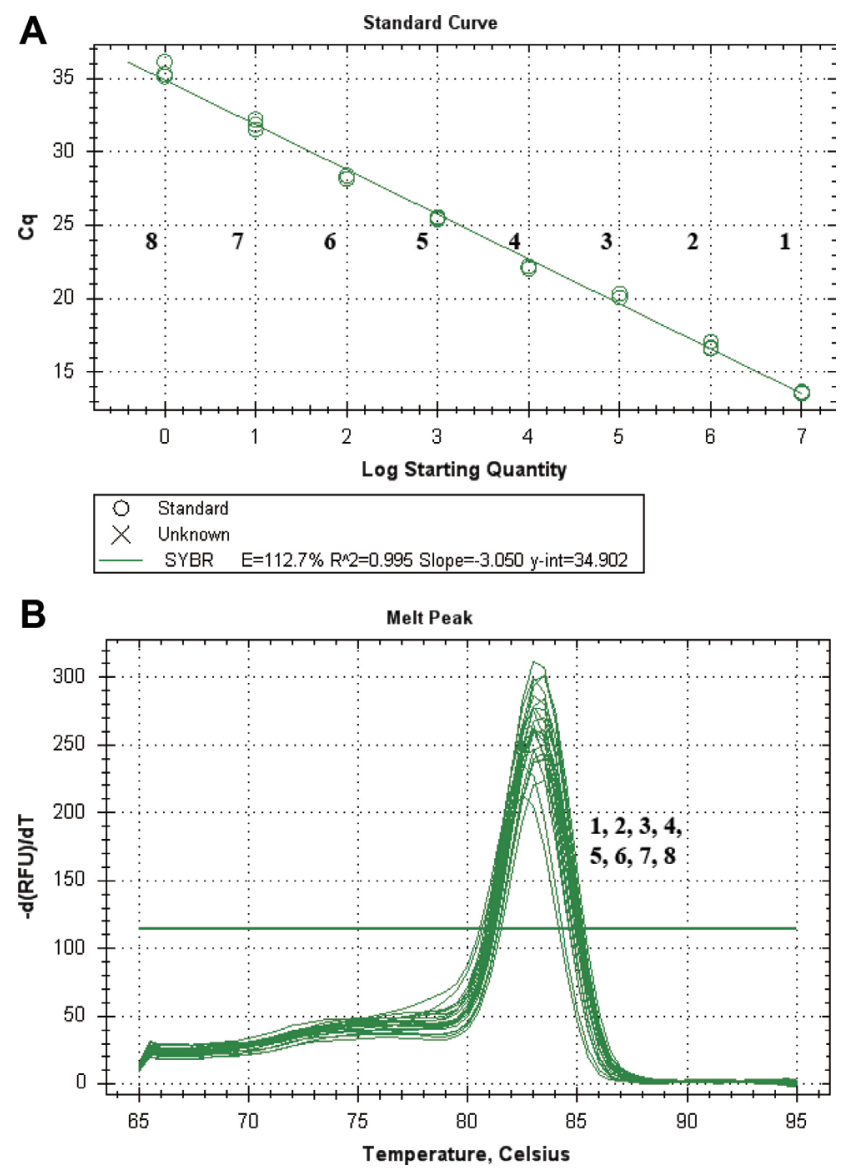

Fig. 3. SYBR Green real-time qPCR with primers Cms89F/R for the quantitative amplification of Clavibacter michiganensis subsp. sepedonicus NCPPB 2137. For each assay, the cloned DNA $\left(1.47 \times 10^{9}\right.$ copies $\left./ \mu 1\right)$ was diluted ten-fold ( $1-8$ sample numbers) and used as a template for PCR. (A) The standard curve that was derived from the amplification plot using ten-fold dilution of cloned DNA (B) A high peak indicates an amplified single product at $83^{\circ} \mathrm{C}$ as melt peak.

known input amount of DNA, the LOD was established as $1.47 \times 10^{2}$ copies $/ \mu$ of cloned-amplified target DNA, $5 \mathrm{fg}$ of DNA using genomic DNA or $10^{-6}$ dilution point of 0.12 at $\mathrm{OD}_{600}$ units of cells per reaction (Table 3). Importantly, when present primer sets compared to the $\mathrm{Cms} 50, \mathrm{Cms} 72 \mathrm{a}$ and celA gene-based primer sets, $\mathrm{Cms} 89$ primer sets were able to detect genomic DNA and bacterial cells at an at least ten-fold higher sensitivity than previous studied primers, respectively.

Detection of the pathogen by quantitative Bio-PCR in tuber infection. Using SYBR green real-time $\mathrm{qPCR}$, the primer set $\mathrm{Cms} 89 \mathrm{~F} / \mathrm{R}$ detected the pathogen in 15 of harvested potato progeny samples from inoculated artificially seed potato. The amplified products that were derived from 
Table 3. Mean Ct end-point fluorescence of 10-fold serial dilutions of Clavibacter michiganensis subsp. sepedonicus cloned DNA, genomic DNA and bacterial cell suspension as determined by the SYBR Green real-time PCR assay

\begin{tabular}{|c|c|c|c|c|c|}
\hline \multicolumn{2}{|c|}{ Cloned DNA } & \multicolumn{2}{|c|}{ Genomic DNA } & \multicolumn{2}{|c|}{ Bacterial Cell suspension $^{a}$} \\
\hline $\begin{array}{l}\text { Copies } / \mu \mathrm{l} \\
\text { reaction mix }\end{array}$ & $C t \pm \mathrm{SD}(n=3)$ & $\begin{array}{c}\text { Weight } / \mu \mathrm{l} \\
\text { reaction mix }\end{array}$ & $C t \pm \mathrm{SD}(n=3)$ & $\begin{array}{l}\text { Ten-fold serial } \\
\text { dilution point }\end{array}$ & $C t \pm \mathrm{SD}(n=3)$ \\
\hline $1.47 \times 10^{9}$ copies & $13.62 \pm 0.07$ & N.D. ${ }^{b}$ & N.D. & N.D. & N.D. \\
\hline $1.47 \times 10^{8}$ copies & $16.81 \pm 0.30$ & $5 \mathrm{ng}$ & $17.20 \pm 0.04$ & 0.12 & $17.76 \pm 0.04$ \\
\hline $1.47 \times 10^{7}$ copies & $20.17 \pm 0.18$ & $500 \mathrm{pg}$ & $19.99 \pm 0.13$ & $0.12\left(10^{-1}\right.$ dilution $)$ & $21.39 \pm 0.02$ \\
\hline $1.47 \times 10^{6}$ copies & $22.11 \pm 0.10$ & $50 \mathrm{pg}$ & $23.24 \pm 0.01$ & $0.12\left(10^{-2}\right.$ dilution $)$ & $24.47 \pm 0.14$ \\
\hline $1.47 \times 10^{5}$ copies & $25.49 \pm 0.08$ & $5 \mathrm{pg}$ & $26.45 \pm 0.06$ & $0.12\left(10^{-3}\right.$ dilution $)$ & $27.50 \pm 0.09$ \\
\hline $1.47 \times 10^{4}$ copies & $28.24 \pm 0.15$ & $500 \mathrm{fg}$ & $29.80 \pm 0.10$ & $0.12\left(10^{-4}\right.$ dilution $)$ & $30.62 \pm 0.06$ \\
\hline $1.47 \times 10^{3}$ copies & $31.86 \pm 0.34$ & $50 \mathrm{fg}$ & $33.20 \pm 0.41$ & $0.12\left(10^{-5}\right.$ dilution $)$ & $33.99 \pm 0.81$ \\
\hline $1.47 \times 10^{2}$ copies & $35.52 \pm 0.62$ & $5 \mathrm{fg}$ & $35.72 \pm 0.34$ & $0.12\left(10^{-6}\right.$ dilution $)$ & $35.95 \pm 0.78$ \\
\hline
\end{tabular}

${ }^{\mathrm{a}} \mathrm{OD}{ }_{600 \mathrm{~nm}}$ unit of cells.

${ }^{b}$ N.D., Not determined.

A

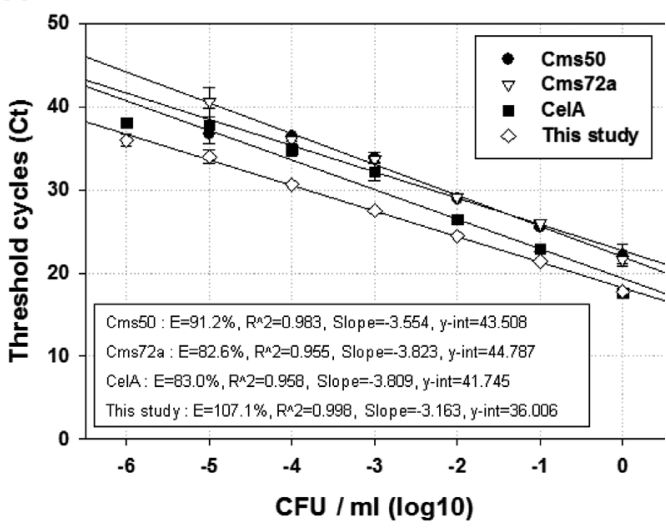

B

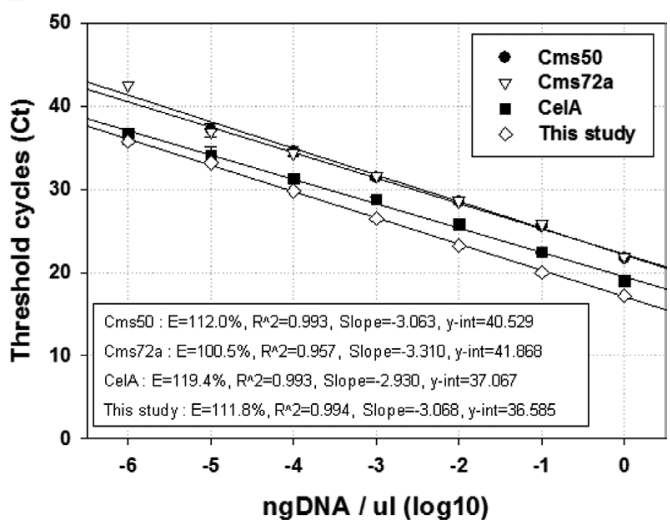

Fig. 4. Sensitivity of Cms89F/R (diamond), CelA (square), Cms50 (circle), and Cms72a (triangle) real-time qPCR primers that were used to detect Clavibacter michiganensis subsp. sepedonicus NCPPB 2137 bacterial cells (A) and the genomic DNA that was extracted from these bacterial cells (B). The reactions were performed in triplicate. The concentrations range of bacterial cell suspension and genomic DNA in PCR reactions are as follow: $0.12 \times 10^{0}$ to $0.12 \times 10^{-6} \mathrm{CFu} / \mathrm{ml}$ of cells per reaction and genomic DNA of $5 \mathrm{ng} / \mu \mathrm{l}$ to $5 \mathrm{fg} / \mu \mathrm{l}$.

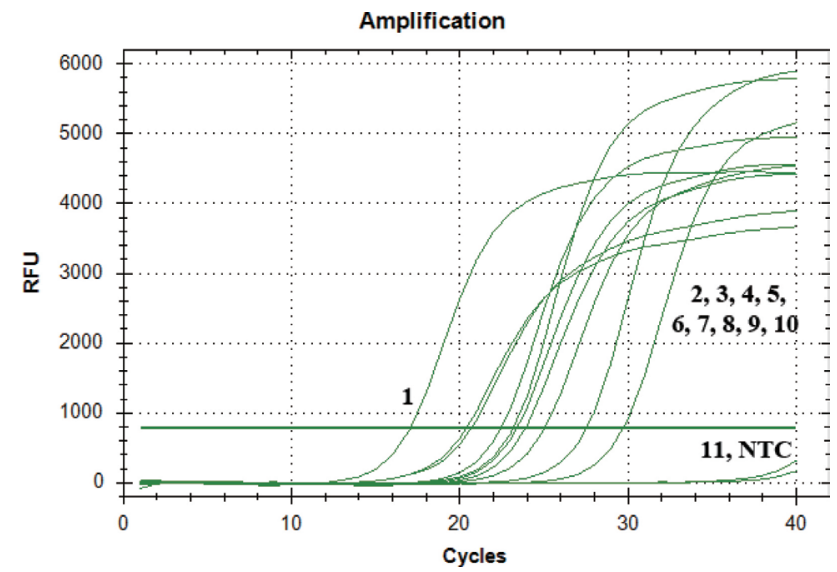

Fig. 5. Specific detection of Clavibacter michiganensis subsp. sepedonicus by SYBR Green real-time Bio-qPCR in an infected potato using the primer set $\mathrm{Cms} 89 \mathrm{~F} / \mathrm{R}$. The fluorescence intensity corresponds to the putative phage-related protein sequences from C. michiganensis subsp. sepedonicus that were amplified using Cms89F/R. 1, C. michiganensis subsp. sepedonicus NCPPB 2137 genomic DNA; 2-10, inoculated potato seedlings; 11, healthy potato seedlings; and 12, no-template control (distilled water). The presented data are from a representative experiment that was repeated twice with similar results.

the tubers both symptom and symptomless showed fluorescence in the SYBR green real-time qPCR assay throughout twice repeat experiments, while no signals were amplified from the healthy potato progeny samples (Fig. 5). The infected potatoes revealed $\mathrm{Ct}$ values ranging from 20 to 30 .

\section{Discussion}

C. michiganensis subsp. sepedonicus is an emerging concern for international quarantine procedures and is an eco- 
nomically important disease for the potato seed industry worldwide. This pathogen can survive in potato tubers for long periods without producing symptoms (Pastrik, 2000). Therefore, sensitive detection and accurate identification are important for the prevention and management of this pathogen. Moreover, there is a high need for specific markers for the earlier detection and identification of $\mathrm{Cms}$ because currently available diagnoses result in large economic losses (Bentley et al., 2008; van der Wolf et al., 2005).

In general, the development of specific primers and DNA probes from the 16S rDNA region (Lee et al., 1997; Li and De Boer, 1995; Mills et al., 1997; Pastrik, 2000; Rademaker and Janse, 1994; Schaad et al., 1999; Schneider et al., 1993), the cellulase A (celA) gene and a small cryptic plasmid ( $p C S 1$ ) to detect $C m s$ by PCR has been proposed (Gudmestad et al., 2009), including multiplex PCR (Pastrik, 2000). However, these assays fail to identify target pathogens and somewhat produce false positives because of critical defects in selecting genes from plasmids or hypothetical proteins (Gudmestad et al., 2009). Therefore, tests are generally invalid, and the designs need to be revised (Phillippy et al., 2007).

Recently, due to the large and increasing numbers of available bacterial sequences in databases, along with the already employed bioinformatics tools, more reliable, rapid and cost-effective methods are developed for bacterial identification from a broad range of samples (Albuquerque et al., 2009; Cho et al., 2011; Lang et al., 2010). This sequence information could be exploited to provide rapid and accurate diagnostics to identify target pathogens and to distinguish the pathogens from other closely related species (Phillippy et al., 2007; Slezak et al., 2003).

In this study, we found the specific sequence region using sequence alignment search methods and developed a primer set for the specific detection of the putative phagerelated protein from the Cms ATCC 33113 genome sequence by accessing information in GenBank (Accession No. AM849034.1, gi|169155030:861988-863124). The putative phage-related protein sequence was analysed by BLAST searches and was found to be highly variable among $C$. michiganensis subspecies. Many researchers who study pathogen identification and the detection of food-borne pathogens have studied various bacteriophage (or phage)-based probes (Casjens and Molineux, 2012; Leiman and Shneider, 2012; Shabani et al., 2008; Singh et al., 2012; Singh et al., 2013; Smartt and Ripp, 2011; Smietana et al., 2011; Zourob and Ripp, 2010). These probes are thermally stable and sensitive, with a high specificity to bacterial cells (Nanduri et al., 2007). Bacterial cells have specific receptor molecules or carbohydrate (polysaccha- ride) sequences outside of the cell that serve as the primary mechanisms by which phages are identified (Golshahi et al., 2011). Therefore, in this study, a SYBR Green realtime qPCR assay for the detection of $\mathrm{Cms}$ based on the putative phage-related protein was developed. To overcome potential false-positive or -negative reactions from $\mathrm{Cms}$ strains, this assay was performed using collections from various geographical origins.

In conclusion, the sensitivity, simplicity and reproducibility of SYBR green real-time qPCR make it suitable as a screening method to detect and quantify $\mathrm{Cms}$ in potato samples, particularly for Cms outbreaks, allowing for more rapid monitoring. The methods that were used in this study are appropriate for analytical purposes with excellent limits of detection and quantification.

\section{Acknowledgments}

This research was supported by Golden Seed Project grant (213001-04-2-WT632), Ministry of Agriculture, Food and Rural Affairs (MAFRA), Ministry of Oceans and Fisheries (MOF), Rural Development Administration (RDA) and Korea Forest Service (KFS), and 2014 Research Grant from Kangwon National University (No. 120140429).

\section{References}

Albuquerque, P., Mendes, M. V., Santos, C. L., Moradas-Ferreira, P. and Tavares, F. 2009. DNA signature-based approaches for bacterial detection and identification. Sci. Total Environ. 407:3641-3651.

Atlas, R. M. 2004. Handbook of microbiological media. 3rd ed. CRC Press, New York.

Bentley, S. D., Corton, C., Brown, S. E., Barron, A., Clark, L., Doggett, J., Harris, B., Ormond, D., Quail, M. A., May, G., Francis, D., Knudson, D., Parkhill, J. and Ishimaru, C. A. 2008. Genome of the actinomycete plant pathogen Clavibacter michiganensis subsp. sepedonicus suggests recent niche adaptation. J. Bacteriol. 190:2150-2160.

Bishop, A. and Slack, S. 1987. Effect of inoculum dose and preparation, strain variation, and plant growth conditions on the eggplant assay for bacterial ring rot. Am. Potato J. 64:227234.

Bonde, R. 1942. Ring rot in volunteer plants. Am. Potato J. 19:131-133.

Casjens, S. R. and Molineux, I. J. 2012. Short noncontractile tail machines: adsorption and DNA delivery by podoviruses. $A d v$. Exp. Med. Biol. 726:143-179.

Che, D., Hasan, M. S. and Chen, B. 2014. Identifying Pathogenicity Islands in Bacterial Pathogenomics Using Computational Approaches. Pathogens 3:36-56.

Chen, J., Zhang, L., Paoli, G. C., Shi, C., Tu, S. and Shi, X. 2010. 
A real-time PCR method for the detection of Salmonella enterica from food using a target sequence identified by comparative genomic analysis. Int. J. Food Microbiol. 137:168174.

Cho, M. S., Kang, M. J., Kim, C. K., Seol, Y., Hahn, J. H., Park, S. C., Hwang, D. J., Ahn, T., Park, D. H., Lim, C. K. and Park, D. S. 2011. Sensitive and specific detection of Xanthomonas oryzae pv. oryzae by real-time bio-PCR using pathovar-specific primers based on an rhs family gene. Plant Dis. 95:589-594.

De Boer, S., Wieczorek, A. and Kummer, A. 1988. An ELISA test for bacterial ring rot of potato with a new monoclonal antibody. Plant Dis. 72:874-878.

De Boer, S. and Wieczorek, A. 1984. Production of monoclonal antibodies to Corynebacterium sepedonicum. Phytopathology 74:1431-1434.

De la Cruz, A., Wiese, M. and Schaad, N. 1992. A semiselective agar medium for isolation of Clavibacter michiganensis subsp. sepedonicus from potato tissues. Plant Dis. 76:830-834.

Golshahi, L., Lynch, K., Dennis, J. and Finlay, W. 2011. In vitro lung delivery of bacteriophages KS4-M and $\Phi \mathrm{KZ}$ using dry powder inhalers for treatment of Burkholderia cepacia complex and Pseudomonas aeruginosa infections in cystic fibrosis. J. Appl. Microbiol. 110:106-117.

Gudmestad, N. C., Mallik, I., Pasche, J. S., Anderson, N. R. and Kinzer, K. 2009. A real-time PCR assay for the detection of Clavibacter michiganensis subsp. sepedonicus based on the cellulase A gene sequence. Plant Dis. 93:649-659.

Gutbrod, O. 1987. Certification policies and practices in reference to bacterial ring rot. Amer. J. Potato Res. 64:677-681.

Hu, X., Lai, F., Reddy, A. and Ishimaru, C. 1995. Quantitative detection of Clavibacter michiganensis subsp. sepedonicus by competitive polymerase chain reaction. Phytopathology 85:1468-1473.

John Schneider, B., Zhao, J. and Orser, C. S. 1993. Detection of Clavibacter michiganensis subsp. sepedonicus by DNA amplification. FEMS Microbiol. Lett. 109:207-212.

Kado, C. I. 2010. Ring Rot of Potatoes. In: Plant Bacteriology. Am. Phytopathol. Soc. pp. 136-140. St. Paul, MN.

Lang, J. M., Hamilton, J. P., Diaz, M. G. Q., Van Sluys, M. A., Burgos, M. R. G., Vera Cruz, C. M., Buell, C. R., Tisserat, N. A. and Leach, J. E. 2010. Genomics-based diagnostic marker development for Xanthomonas oryzae pv. oryzae and X. oryzae pv. oryzicola. Plant Dis. 94:311-319.

Lee, I. M., Bartoszyk, I. M., Gundersen, D. E., Mogen, B. and Davis, R. E. 1997. Nested PCR for ultrasensitive detection of the potato ring rot bacterium, Clavibacter michiganensis subsp. sepedonicus. Appl. Environ. Microbiol. 63:2625-2630.

Leiman, P. G. and Shneider, M. M. 2012. Contractile tail machines of bacteriophages. Adv. Exp. Med. Biol. 726:93-114.

Li, W., Hartung, J. S. and Levy, L. 2006. Quantitative real-time PCR for detection and identification of Candidatus Liberibacter species associated with citrus huanglongbing. J. Microbiol. Methods 66:104-115.

Mackay, I. M., Arden, K. E. and Nitsche, A. 2002. Real-time
PCR in virology. Nucleic Acids Res. 30:1292-1305.

Manzer, F. and Genereux, H. 1981. Ring rot. In: Compendium of Potato Diseases. ed. by W. J. Hooker, pp. 31-32. Am. Phytopathol. Soc. St. Paul, Mn.

Mills, D., Russell, B. W. and Hanus, J. W. 1997. Specific detection of Clavibacter michiganensis subsp. sepedonicus by amplification of three unique DNA sequences isolated by subtraction hybridization. Phytopathology 87:853-861.

Nanduri, V., Sorokulova, I. B., Samoylov, A. M., Simonian, A. L., Petrenko, V. A. and Vodyanoy, V. 2007. Phage as a molecular recognition element in biosensors immobilized by physical adsorption. Biosens. Bioelectron. 22:986-992.

Pastrik, K. 2000. Detection of Clavibacter michiganensis subsp. sepedonicus in potato tubers by multiplex PCR with coamplification of host DNA. Eur. J. Plant Pathol. 106:155-165.

Phillippy, A. M., Mason, J. A., Ayanbule, K., Sommer, D. D., Taviani, E., Huq, A., Colwell, R. R., Knight, I. T. and Salzberg, S. L. 2007. Comprehensive DNA signature discovery and validation. PLoS Comput. Biol. 3:e98.

Rademaker, J. and Janse, J. 1994. Detection and identification of Clavibacter michiganensis subsp. sepedonicus and Clavibacter michiganensis subsp. michiganensis by nonradioactive hybridization, polymerase chain reaction, and restriction enzyme analysis. Can. J. Microbiol. 40:1007-1018.

Schaad, N., Berthier-Schaad, Y., Sechler, A. and Knorr, D. 1999. Detection of Clavibacter michiganensis subsp. sepedonicus in potato tubers by BIO-PCR and an automated real-time fluorescence detection system. Plant Dis. 83:1095-1100.

Shabani, A., Zourob, M., Allain, B., Marquette, C. A., Lawrence, M. F. and Mandeville, R. 2008. Bacteriophage-modified microarrays for the direct impedimetric detection of bacteria. Anal. Chem. 80:9475-9482.

Singh, A., Poshtiban, S. and Evoy, S. 2013. Recent advances in bacteriophage based biosensors for food-borne pathogen detection. Sensors 13:1763-1786.

Singh, A., Arutyunov, D., Szymanski, C. M. and Evoy, S. 2012. Bacteriophage based probes for pathogen detection. Analyst 137:3405-3421.

Slack, S., Drennan, J., Westra, A., Gudmestad, N. and Oleson, A. 1996. Comparison of PCR, ELISA, and DNA hybridization for the detection of Clavibacter michiganensis subsp. sepedonicus in field-grown potatoes. Plant Dis. 80:519-524.

Slezak, T., Kuczmarski, T., Ott, L., Torres, C., Medeiros, D., Smith, J., Truitt, B., Mulakken, N., Lam, M., Vitalis, E., Zemla, A., Zhou, C. E. and Gardner, S. 2003. Comparative genomics tools applied to bioterrorism defence. Brief Bioinform 4:133-149.

Smartt, A. E. and Ripp, S. 2011. Bacteriophage reporter technology for sensing and detecting microbial targets. Anal. Bioanal. Chem. 400:991-1007.

Smietana, M., Bock, W. J., Mikulic, P., Ng, A., Chinnappan, R. and Zourob, M. 2011. Detection of bacteria using bacteriophages as recognition elements immobilized on long-period fiber gratings. Optics Express 19:7971-7978. 
Whelan, J. A., Russell, N. B. and Whelan, M. A. 2003. A method for the absolute quantification of cDNA using real-time PCR. J. Immunol. Methods 278:261-269.

Wolf, J., Elphinstone, J., Stead, D., Metzler, M., Müller, P., Hukkanen, A. and Karjalainen, R. 2005. Epidemiology of Clavibacter michiganensis subsp. sepedonicus in relation to control of bacterial ring rot. Report 95. Plant Research International B. V., Wageningen.
Xiang, L. and De Boer, S. H. 1995. Selection of polymerase chain reaction primers from an RNA intergenic spacer region for specific detection of Clavibacter michiganensis subsp. sepedonicus. Phytopathology 85:837-842.

Zourob, M. and Ripp, S. 2010. Bacteriophage-based biosensors. In: Recognition receptors in biosensors, ed. by. M. Zourob. pp. 415-448. Springer, New York. 